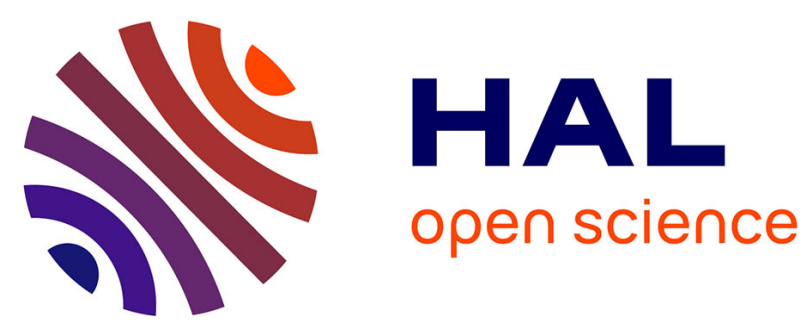

\title{
Rational design of a novel turn-on fluorescent probe for the detection and bioimaging of hydrazine with barbituric acid as a recognition group
}

Junli Du, Xiaolu Li, Songsong Ruan, Yingchun Li, Fan Ren, Yanjun Cao, Xiaoqing Wang, Yongmin Zhang, Shaoping Wu, Jianli Li

\section{To cite this version:}

Junli Du, Xiaolu Li, Songsong Ruan, Yingchun Li, Fan Ren, et al.. Rational design of a novel turn-on fluorescent probe for the detection and bioimaging of hydrazine with barbituric acid as a recognition group. Analyst, 2020, 145 (2), pp.636-642. 10.1039/c9an02058f . hal-02864856

\section{HAL Id: hal-02864856 https://hal.sorbonne-universite.fr/hal-02864856}

Submitted on 11 Jun 2020

HAL is a multi-disciplinary open access archive for the deposit and dissemination of scientific research documents, whether they are published or not. The documents may come from teaching and research institutions in France or abroad, or from public or private research centers.
L'archive ouverte pluridisciplinaire HAL, est destinée au dépôt et à la diffusion de documents scientifiques de niveau recherche, publiés ou non, émanant des établissements d'enseignement et de recherche français ou étrangers, des laboratoires publics ou privés. 


\section{Rational design of a novel turn-on fluorescent probe for detecting}

hydrazine with barbituric acid as recognition group and bioimaging Junli $\mathrm{Du}^{\mathrm{a}}{ }^{\mathrm{a} b}$, Xiaolu $\mathrm{Li}^{\mathrm{a}}$, , Songsong Ruan ${ }^{\mathrm{a}, \mathrm{b}}$, Yingchun $\mathrm{Li}^{\mathrm{a}}$, Fan Ren ${ }^{\mathrm{a}, \mathrm{b}}$, Yanjun $\mathrm{Cao}^{\mathrm{a}}$, Xiaoqing Wang ${ }^{\mathrm{c}}$, Yongmin Zhang ${ }^{\mathrm{a}, \mathrm{b}, \mathrm{d}}$, Shaoping $\mathrm{Wu}^{\mathrm{a}, \mathrm{b}^{*}}$, Jianli $\mathrm{Li}^{\mathrm{c}}$

${ }^{a}$ School of Pharmacy; Key Laboratory of Resource Biology and Biotechnology in Western China (Northwest University), Ministry of Education; Biomedicine Key Laboratory of Shaanxi Province, Northwest University, Xi'an 710069, China

${ }^{\mathrm{b}}$ Joint International Laboratory of Glycobiology and Medicinal Chemistry, Northwest University, Xi'an, Shaanxi 710069, China

${ }^{c}$ Key Laboratory of Synthetic and Natural Functional Molecule Chemistry of Ministry of Education, College of Chemistry \& Materials Science, Northwest University, Xi'an, Shaanxi 710127, P. R. China

${ }^{\mathrm{d}}$ Sorbonne Université, Institut Parisien de Chimie Moléculaire, CNRS UMR 8232, 4 place Jussieu, 75005 Paris, France

* Tel.: +86 029 88304569; Fax: +86 029 88304569. E-mail: wushaoping@ @wu.edu.cn

Keywords: Fluorescent probe, Hydrazine, Barbituric acid, Large Stokes shift, Bioimaging

\section{ABSTRACT:}

A novel turn-on fluorescent probe with barbituric acid as a unique recognition group has been rational designed and facile synthesized for detecting hydrazine. Probe DPT displays a large emission signal ratio variation (more 40 -fold enhancement) in the presence of hydrazine under neutral conditions. Interestingly, a novel recognition mechanism based on the hydrazine-triggered addition-cyclisation-retro aldol was proposed and confirmed. Additionally, probe DPT exhibits a low detection limit $\left(5 \times 10^{-8} \mathrm{M}\right)$, applicability in physiological $\mathrm{pH}$ range (3 12), a broad linear response range of the hydrazine concentration between 0 and $34 \mu \mathrm{M}$ and large Stokes shift (147 $\mathrm{nm})$ for hydrazine detection in aqueous solution. Moreover, probe DPT was triumphantly implemented for hydrazine imaging in vivo. 


\section{Introduction}

Hydrazine $\left(\mathrm{NH}_{2} \mathrm{NH}_{2}\right)$ is a kind of extremely reactive base which could be used in various fields, such as chemical, pharmaceutical, industrial and agricultural [1,2]. Statistical results indicate that more than 120000 tons of approximately $64 \%$ hydrazine hydrate solutions are produced globally per year [3]. The spread of hydrazine would inevitably generate harm to the environment and human beings due to its high solubility in water. It could drive serious impairment to protein and nucleic acid structures. Hence hydrazine may cause severe organ injuries if excess exposure, such as liver, kidneys and the central nervous system [4,5]. Additionally, the U.S. Environmental Protection Agency advised a maximum threshold limit value of $10 \mathrm{ppb}$ $(0.31 \mu \mathrm{M})$ of hydrazine in drinking water as a carcinogenic substance [6,7]. Therefore, developing a kind of concise and efficient tool for the trace amounts of hydrazine detection in vitro and environment is of great significance, and also important to protect human health as well as understand its functions in complicated biological systems.

Up to now, a lot of traditional methods for the determination of hydrazine have been exploited, such as titrimetry [8], chromatography [9,10], capillary electrophoresis [11], electrochemical analysis [12,13], chemiluminescence [14], microflow detection [15] and so on. However, these analytical methods require complicated sample pretreatment which needs long time, high instrumentation cost and professional operation. Specially, individual methods may even produce damage to cell or tissues, thus becoming not appropriate for analyzing hydrazine in vivo and cell imaging. These shortcomings could limit the application of these methods. Therefore, fluorescence probe [16] based on sensing of hydrazine is receiving increased attention on account of its easy execution, low-priced, unique selectivity, extremely low sensitivity and on site analysis.

So far, a variety of dyes scaffold have been designed and synthesized for detecting hydrazine based on different responsive mechanism, such as rhodamine [17], BODIPY [18,19], coumarin [20,21], resorufin [22,23], benzothiazole [24,25], 
heptamethine cyanine and hemicyanine [26,27]. On the other hand, a lot of fluorescent probes for hydrazine have been reported on the strength of three different mechanisms, including selective reaction with arylidenemalononitrile [28, 29], selective deprotection of levulinoyl ester or acetyl groups [30,31,32], condensation with arylaldehydes $[33,34]$, phthalimide [35,36] and 4-bromo butyrate $[37,38,39]$. However, the available fluorescent probes for hydrazine detection have some shortcoming. Hence, the design of novel fluorescent probe scaffold and its unique reaction mechanism for hydrazine is still a challenge which requires fast response time and high selectivity for the detection of hydrazine.

In this article, a novel colorimetric and turn on fluorescent probe with barbituric acid as a unique recognition group has been rational designed and facile synthesized for detecting hydrazine (Fig. 1). As expected, probe DPT shows an emission peaks at $527 \mathrm{~nm}$, excitations at $380 \mathrm{~nm}$ and display a large emission signal ratio variation (more 40-fold enhancement) in the presence of hydrazine under neutral conditions. Surprisingly, a novel recognition mechanism based on retro-aldol reaction was confirmed. Additionally, probe DPT exhibits a low detection limit $\left(5 \times 10^{-8} \mathrm{M}\right)$, applicability in physiological $\mathrm{pH}$ range, a broad linear response range of the hydrazine concentration from 0 to $34 \mu \mathrm{M}$ and large Stokes shift $(147 \mathrm{~nm})$ for hydrazine detection at physiological conditions. Furthermore, probe DPT was successfully utilized for cell imaging hydrazine in living cells.

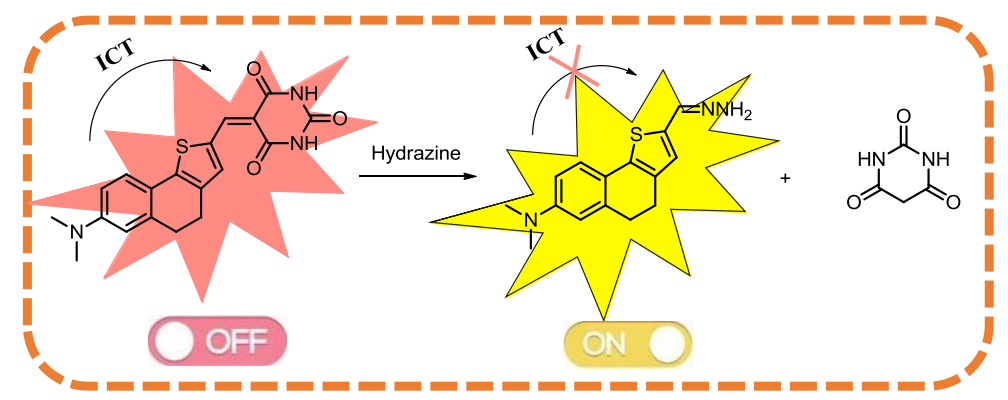

Fig. 1. Proposed mechanism of probe DPT towards hydrazine.

\section{Materials and methods}

\subsection{Materials and Instrumentation}

All solvents and chemical reagents for synthesis were commercially available. 
6-amino-1-tetralone, hydrazine monohydrate solution, sodium sulphide and chloroacetaldehyde were purchased from $J \& K$ Shanghai Scientific Ltd in China. Stock solution of hydrazine was prepared from the commercial hydrazine monohydrate reagent. The UV-vis spectra were measured on a Shimadzu UV-2550 and the fluorescence spectra were performed via Hitachi F-7000 spectrophotometer. The cell imaging was collected by the FV1000 laser confocal fluorescence microscope of Olympus Company.

2.2. Synthesis of probe 5-((7-(dimethylamino)-4,5-dihydronaphtho [1,2-b] thiophen-2-yl)methylene)pyrimidine-2,4,6 (1H,3H,5H)-trione (DPT)

Compound 2 (50.0 mg, 0.195 mmol, 1.0 equiv.) and barbituric acid (37.4 mg, 0.29 mmol, 1.5 equiv.) in dry EtOH $(5.0 \mathrm{~mL})$ was blended at $25^{\circ} \mathrm{C}$, then $0.5 \mathrm{~mL}$ of acetic acid glacial was added as catalyst. The reaction mixture was heated for $2 \mathrm{~h}$ at $85{ }^{\circ} \mathrm{C}$ The formed precipitate was filtered off by funnel, washed with ice ethanol and dried in vacuum, the pure probe DPT was obtained as a black powder (yield: $75.5 \%, \mathrm{R}_{\mathrm{f}}=$ 0.74). ${ }^{1} \mathrm{H}$ NMR (600 MHz, TFA- $\left.d_{1}\right) \delta 11.50(\mathrm{~s}, 1 \mathrm{H}), 11.50(\mathrm{~s}, 1 \mathrm{H}), 8.88$ (s, 1H), 7.91 $(\mathrm{s}, 1 \mathrm{H}), 7.87(\mathrm{~s}, 1 \mathrm{H}), 7.51(\mathrm{~s}, 2 \mathrm{H}), 3.41(\mathrm{~s}, 6 \mathrm{H}), 3.08(\mathrm{~s}, 2 \mathrm{H}), 2.98(\mathrm{~s}, 2 \mathrm{H}) .{ }^{13} \mathrm{C} \mathrm{NMR}$ $\left(151 \mathrm{MHz}, \mathrm{TFA}-d_{1}\right) \delta 163.62,155.71,151.84,151.74,151.11,141.74,140.97,135.55$, 131.98, 126.72, 126.23, 119.59, 118.94, 118.18, 117.55, 105.01, 46.27, 27.23, 20.98. HRMS $\left(\mathrm{C}_{19} \mathrm{H}_{17} \mathrm{~N}_{3} \mathrm{O}_{3} \mathrm{~S}\right)$ : calcd. for [M-H] $]^{-}$366.0912; found: [M-H] 366.0913 (Fig. S4-S6).

\subsection{Titration experiments of probe DPT}

A stock solution of probe DPT （1.0 mM in DMF） was prepared for spectrum titrations. The $1.0 \mathrm{mM}$ solution of $\mathrm{N}_{2} \mathrm{H}_{4} \cdot \mathrm{H}_{2} \mathrm{O}$ was readied in pure water. Usually, test solutions were prepared by adding $30 \mu \mathrm{L}$ of the DPT stock solution into a $5 \mathrm{~mL}$ colorimetric tube, diluting the solution with $10 \mathrm{mM}$ PBS buffer solution $(\mathrm{pH}=7.4$, $20 \%$ DMSO). Then different analyte was dissolved in ultrapure water and respectively added into the test solution. 
The cytotoxicity of probe DPT was detected using cell counting kit-8 (CCK-8). SH-SY5Y neuroblastoma cell was afforded from the ATCC Cell Bank. The cells were cultured for $24 \mathrm{~h}$ at $37{ }^{\circ} \mathrm{C}$ with $5 \% \mathrm{CO}_{2}$ in DMEM (supplemented with $10 \%$ fetal bovine serum (FBS)) after it was seeded in 96-well plates at a moderate density of cells per well. Then the cells were hatched with probe DPT at $0,5,10,15,20 \mu \mathrm{M}$ concentrations for $24 \mathrm{~h}$, next $10 \mu \mathrm{L}$ CCK-8 solution was added to each hole of the 96-well plate for $2 \mathrm{~h}$ at $37^{\circ} \mathrm{C}$, the absorbance of cells were recorded by a microplate reader at $450 \mathrm{~nm}$. Each treatment group was repeated five times.

\subsection{Imaging of probe DPT in living cell}

For cell imaging of hydrazine, the SH-SY5Y neuroblastoma cell was put into a $10 \mathrm{~mm}$ diameter culture vessel and permitted to adhere for $24 \mathrm{~h}$. Before cell imaging, the SH-SY5Y neuroblastoma cells were hatched with $10 \mu \mathrm{M}$ probe DPT at $37^{\circ} \mathrm{C}$ for 5 min, and followed by lavation three times with $\mathrm{pH}=7.4 \mathrm{PBS}$ buffer solution to move out overabundance DPT, next in situ treated with $0,10,20,30 \mu \mathrm{M}$ concentrations of $\mathrm{N}_{2} \mathrm{H}_{4} \cdot \mathrm{H}_{2} \mathrm{O}$ solution at $37{ }^{\circ} \mathrm{C}$ for 15 min, respectively. Then the cells were performed with a laser confocal microscope after it was laundered with PBS three times to move out excess ions.

\section{Results and discussion}

\subsection{Design and synthesis of probe DPT}

As detailed in Scheme 1, probe DPT was rationally designed and conveniently synthesized in one step. Starting material 6-amino-1-tetralone is commercially available. Compound 1 was generated by dimethylation of 6-amino-1-tetralone with methyl iodide and $\mathrm{K}_{2} \mathrm{CO}_{3}$ in DMF [40]. The aldehyde-chloride compound was generated which was utilized to produce compound 2 with $\mathrm{Na}_{2} \mathrm{~S}$ in chloroacetaldehyde and $\mathrm{K}_{2} \mathrm{CO}_{3}$ at $60{ }^{\circ} \mathrm{C}$ [41]. Ultimately, the compound 2 was reacted with barbituric acid in absolute ethanol solution to obtain probe DPT at $85{ }^{\circ} \mathrm{C}$ [42]. The elaborated synthetic protocols were delineated in the supplementary Material. 


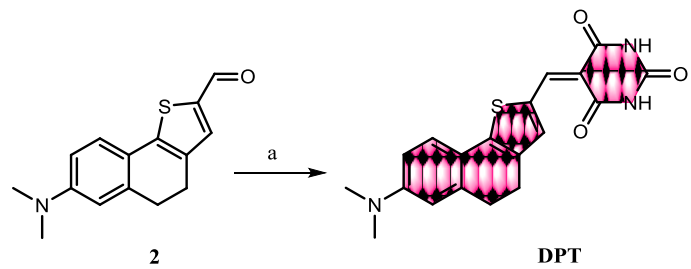

Scheme 1. Reagents and conditions: (a) Barbituric acid, Ethanol, reflux, $85^{\circ} \mathrm{C}, 2 \mathrm{~h}, 75.5 \%$.

\subsection{UV-vis absorbance and fluorescence spectra study}

The excitation and emission spectra of probe DPT were explored in 20\% DMSO co-solution with $10.0 \mathrm{mM}$ PBS buffer solution ( $\mathrm{pH} 7.4)$ at $25{ }^{\circ} \mathrm{C}$. As a structurally novel probe, DPT was assessed for its UV-vis and fluorescence properties in various kind polarity solvents including $\mathrm{MeOH}, \mathrm{EtOH}, \mathrm{ACN}, \mathrm{DMK}, \mathrm{DMSO}$, DMF, TCM, DCM, EtOAc, $\mathrm{H}_{2} \mathrm{O}$, THF and so on. At the same time, the fluorescence quantum yield of DPT- $\mathbf{N}_{2} \mathbf{H}_{4}$ addition compound was calculated via fluorescein $\left(\Phi_{f}=0.92,0.1 \mathrm{M}\right.$ $\mathrm{NaOH})$ as the standard compound. The detailed photophysical properties of probe DPT were illustrated in Table $\mathbf{S 2}$.

The absorbance spectral responses of probe DPT toward hydrazine have been measured in the mixture solvent of $20 \%$ DMSO and $10.0 \mathrm{mM}$ PBS buffer system $(\mathrm{pH}$ 7.4). As depicted in Fig. 2, the absorbance peak at $585 \mathrm{~nm}$ was increased by degrees and had an excellent linear functional relationship with hydrazine between 0 and 20 $\mu \mathrm{M}\left(\mathrm{R}^{2}=0.9942\right)$ along with the hydrazine concentration increase. Meanwhile, the color change of the solution from blue purple to colorless also can be distinctly observed along with these absorption value changes under daylight lamp in Fig. 4a. So probe DPT could be used as naked eye visible hydrazine sensors in aqueous solution owing to their sensitive color sense to the solution hydrazine color change.
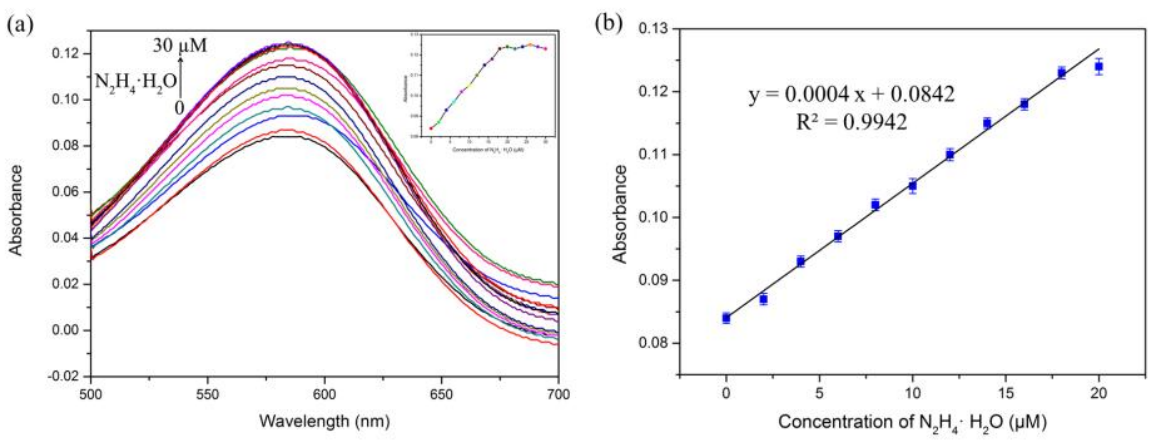
Fig. 2. (a) UV-vis absorption spectra of probe DPT $(6 \mu \mathrm{M})$ upon addition of $0 \sim 30 \mu \mathrm{M} \mathrm{N} \mathrm{N}_{2} \mathrm{H}_{4} \cdot \mathrm{H}_{2} \mathrm{O}$ in a 20\% DMSO solution and $10.0 \mathrm{mM}$ PBS buffer, $\mathrm{pH}$ 7.4. (b) Linear relationships between UV-vis absorbance at $585 \mathrm{~nm}$ and concentrations of $\mathrm{N}_{2} \mathrm{H}_{4} \cdot \mathrm{H}_{2} \mathrm{O}$.

The fluorescent response of probe DPT to hydrazine was shown in Fig. 3, probe DPT itself had weak fluorescence emission at $650 \mathrm{~nm}$, but the fluorescence intensity gradually increased along with enhancement in hydrazine concentration changes at $525 \mathrm{~nm}$ with a wide emission band from $450 \mathrm{~nm}$ to $650 \mathrm{~nm}$. Additionally, between the florescence intensities with hydrazine concentration have a good linearity $\left(\mathrm{R}^{2}=\right.$ 0.9982 ) in $0 \sim 26 \mu \mathrm{M}$, the regression equation was $\mathrm{Y}=361.7531 \mathrm{X}-66.1829$ from the linear calibration graphs with the fluorescence titration experiments. On the other hand, the minimum LOD of probe DPT for hydrazine was $50 \mathrm{nM}$ using signal to noise ratio $(\mathrm{S} / \mathrm{N})=3$, it was satisfied to the detection of hydrazine. Further experiments phenomenon indicated that the fluorescent color change from light red to yellow is shown in Fig. $\mathbf{4 b}$ at $365 \mathrm{~nm}$ light. These data illustrated that probe DPT could be an excellent on-off-type fluorescent probe to detect hydrazine concentration quantitatively in complicated background sample.
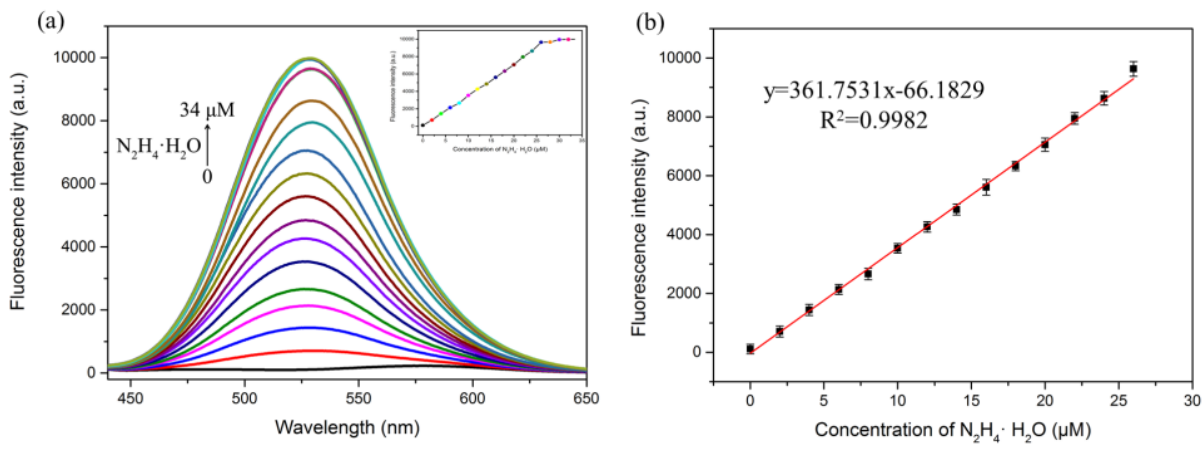

Fig. 3. (a) Fluorescence titration spectra of probe DPT $(6 \mu \mathrm{M})$ upon addition of $0 \sim 34 \mu \mathrm{M}$ $\mathrm{N}_{2} \mathrm{H}_{4} \cdot \mathrm{H}_{2} \mathrm{O}$ in $10 \mathrm{mM}$ PBS (pH 7.4, containing $20 \%$ DMSO). $\lambda_{\mathrm{ex}}=380 \mathrm{~nm}, \lambda_{\mathrm{em}}=525 \mathrm{~nm}$. slit: 5.0 $\mathrm{nm} / 5.0 \mathrm{~nm}$. (b) Linear relationship between probe DPT $(6 \mu \mathrm{M})$ at $525 \mathrm{~nm}$ and $\mathrm{N}_{2} \mathrm{H}_{4} \cdot \mathrm{H}_{2} \mathrm{O}$ concentration $(0 \sim 26 \mu \mathrm{M})$.

(a)

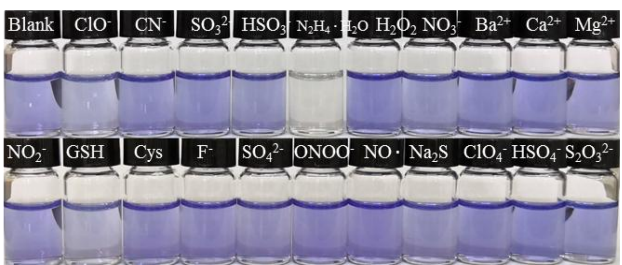

(b)

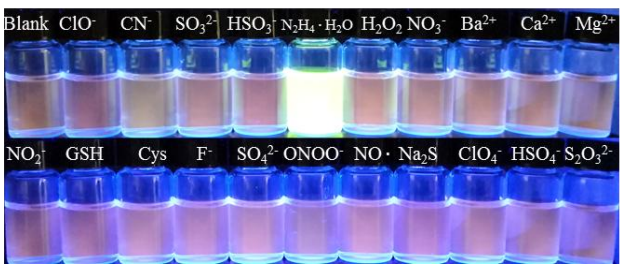

Fig. 4. Color change of probe DPT solution upon addition various ions under daylight lamp (a) and ultraviolet lamp (b). Fluorescence $\left(\lambda_{\mathrm{ex}}=365 \mathrm{~nm}\right)$ change upon addition of different metal ions 
and anions in PBS buffer ( $\mathrm{pH} 7.4,10 \mathrm{mM}$, containing 20\% DMSO) solution. (From left to right: Blank, $\mathrm{ClO}^{-}, \mathrm{CN}^{-}, \mathrm{SO}_{3}{ }^{2-}, \mathrm{HSO}_{3}^{-}, \mathrm{H}_{2} \mathrm{O}_{2}, \mathrm{NO}_{3}^{-}, \mathrm{Ba}^{2+}, \mathrm{Ca}^{2+}, \mathrm{Mg}^{2+}, \mathrm{NO}_{2}^{-}, \mathrm{GSH}, \mathrm{Cys}, \mathrm{F}, \mathrm{SO}_{4}^{2-}$, $\mathrm{ONOO}^{-}, \mathrm{NO} \cdot \mathrm{Na}_{2} \mathrm{~S}, \mathrm{ClO}_{4}^{-}, \mathrm{HSO}_{4}^{-}, \mathrm{S}_{2} \mathrm{O}_{3}{ }^{2-}, \mathrm{N}_{2} \mathrm{H}_{4} \cdot \mathrm{H}_{2} \mathrm{O}$ ).

\subsection{Selectivity and competitive experiment}

The selectivity of probe DPT toward $\mathrm{N}_{2} \mathrm{H}_{4} \cdot \mathrm{H}_{2} \mathrm{O}$ were investigated by various biologically relevant analytes including anions, cations and ROS. As displayed in Fig. 5a, only the fluorescence intensity ration of probe DPT markedly raised along with the addition of $\mathrm{N}_{2} \mathrm{H}_{4} \cdot \mathrm{H}_{2} \mathrm{O}$, the fluorescence intensity was no obvious changed along with addition of other analytes in the same condition.

Next the anti-interference property of probe DPT with various analytes has been also studied as shown in Fig. 5b, the detection of $\mathrm{N}_{2} \mathrm{H}_{4} \cdot \mathrm{H}_{2} \mathrm{O}$ did not interfere in present the of all the competing analytes, these outcomes suggested that probe DPT has unique selectivity for $\mathrm{N}_{2} \mathrm{H}_{4} \cdot \mathrm{H}_{2} \mathrm{O}$ over multifarious interfering species that could be exist in living cells and environment. In a word, it was capacitated to monitor $\mathrm{N}_{2} \mathrm{H}_{4} \cdot \mathrm{H}_{2} \mathrm{O}$ in sophisticated biological sample.

(a)

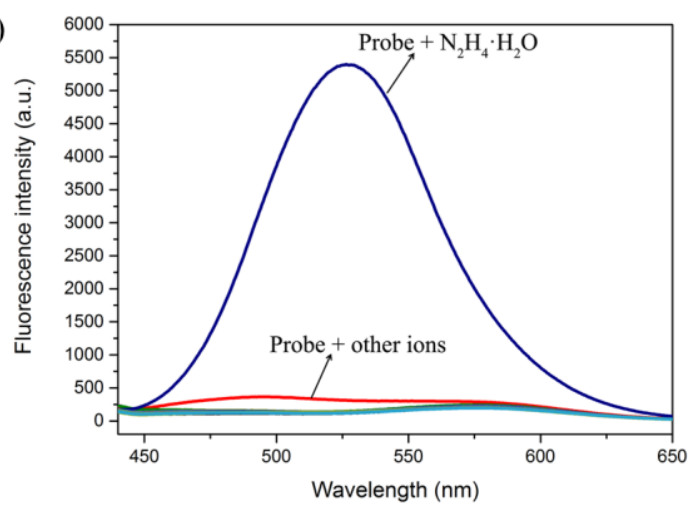

(b)

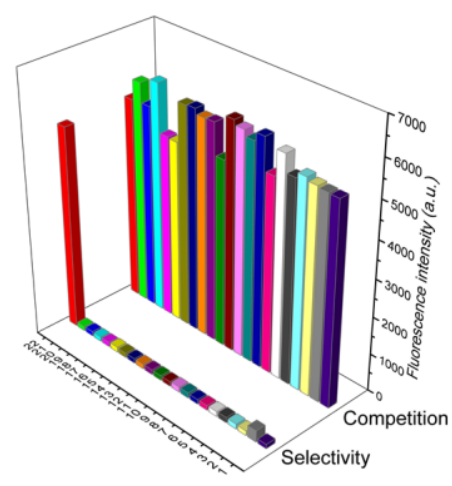

Fig. 5. (a) Fluorescence spectra of probe DPT $(6 \mu \mathrm{M})$ upon addition $20 \mu \mathrm{M}$ of different ions in PBS buffer (pH 7.4, $10 \mathrm{mM}$, containing 20\% DMSO) solution $\left(\lambda_{\mathrm{ex}}=380 \mathrm{~nm}\right.$, slit $=5.0 \mathrm{~nm} / 5.0$ $\mathrm{nm}$ ). (b) The pillars in the front row represent fluorescence response of the probe to the metal ions of interest. The pillars in the back row represent the subsequent addition $20 \mu \mathrm{M} \mathrm{N} \mathrm{N}_{2} \mathrm{H}_{4} \cdot \mathrm{H}_{2} \mathrm{O}$ to the solution containing probe and the metal ions, respectively. (1. Blank, 2. $\mathrm{ClO}^{-}, 3 . \mathrm{CN}^{-}, 4 . \mathrm{SO}_{3}^{2-}, 5$. $\mathrm{HSO}_{3}^{-}, 6 . \mathrm{H}_{2} \mathrm{O}_{2}, 7 . \mathrm{NO}_{3}^{-}, 8 . \mathrm{Ba}^{2+}, 9 . \mathrm{Ca}^{2+}, 10 . \mathrm{Mg}^{2+}, 11 . \mathrm{NO}_{2}^{-}, 12 . \mathrm{GSH}, 13 . \mathrm{Cys}, 14 . \mathrm{F}, 15 . \mathrm{SO}_{4}{ }^{2-}$, 16. $\mathrm{ONOO}^{-}, 17$. NO., 18. $\mathrm{Na}_{2} \mathrm{~S}, 19 . \mathrm{ClO}_{4}^{-}, 20 . \mathrm{HSO}_{4}^{-}, 21 . \mathrm{S}_{2} \mathrm{O}_{3}{ }^{2-}, 22 . \mathrm{N}_{2} \mathrm{H}_{4} \cdot \mathrm{H}_{2} \mathrm{O}$ ).

\subsection{Time kinetic and $\mathrm{pH}$-tolerability of probe DPT}

The reaction kinetics is a vital factor for the optical signal changing between probe DPT and hydrazine concentration, so the response kinetics of probe DPT to 
hydrazine was also investigated. As displayed in Fig. 6a, a plateau of fluorescence intensity changes could be achieved within 10 min upon addition of $20 \mu \mathrm{M}$ of hydrazine in the probe aqueous solution. Therefore, we selected $10 \mathrm{~min}$ as the optimum reaction time in the all experiments.

For the sake of the complex biological sample applications, the optimal $\mathrm{pH}$ range of probe DPT is crucial to be found. The fluorescence intensity of individual probe DPT and probe DPT with $\mathrm{N}_{2} \mathrm{H}_{4} \cdot \mathrm{H}_{2} \mathrm{O}$ were investigated in $20 \%$ DMSO aqueous solution under different $\mathrm{pH}$ values, respectively. It was found that probe DPT did not display any remarkable fluorescence intensity change in the wide $\mathrm{pH}$ range of 3 12. Furthermore, the mixture solution of probe DPT with hydrazine showed a outstanding fluorescence increase at $525 \mathrm{~nm}$ and the fluorescence intensity was a very little change in the wide $\mathrm{pH}$ range of 5 10. These results show that probe DPT and DPT$\mathbf{N}_{2} \mathbf{H}_{4}$ were very stable in the wide $\mathrm{pH}$ range of $3 \sim 12$, which indicates probe DPT is suitable for detection of hydrazine concentration in vivo and in vitro sample under physiological conditions.
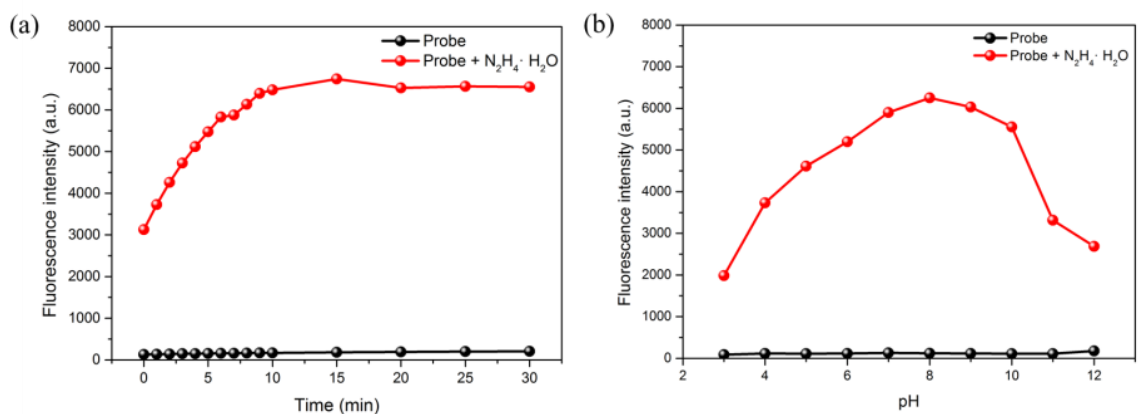

Fig. 6. (a) Time-kinetic fluorescence changes of probe DPT $(6 \mu \mathrm{M})$ with $\mathrm{N}_{2} \mathrm{H}_{4} \cdot \mathrm{H}_{2} \mathrm{O}(20 \mu \mathrm{M})$ in 10 mM PBS (pH 7.4, 20\% DMSO). (b) Changes in fluorescence spectra of probe DPT $(6 \mu \mathrm{M})$ in the absence and present of $\mathrm{N}_{2} \mathrm{H}_{4} \cdot \mathrm{H}_{2} \mathrm{O}(20 \mu \mathrm{M})$ as a function of $\mathrm{pH}$. $\lambda_{\mathrm{ex}}=380 \mathrm{~nm}$, slits: $5.0 \mathrm{~nm} / 5.0 \mathrm{~nm}$.

\subsection{Recognition mechanism and theoretical computation}

On the basis of these spectral results, the proposed recognition mechanism of probe DPT toward hydrazine is speculated as follows: in the presence of hydrazine, the barbituric acid moiety bearing on probe DPT could react with hydrazine by addition reaction, and then the intermediate alcohol would turn into keto by transformation of enol. Then the barbituric acid moiety would be released by retro-aldol reaction to provide the elimination product DPT- $\mathbf{N}_{2} \mathbf{H}_{4}$ (Scheme 2). The 
proposed recognition mechanism was confirmed by MS spectrum, DPT $\quad(50 \mu \mathrm{M})$ and hydrazine $(60 \mu \mathrm{M})$ was reacted each other for $5 \mathrm{~min}$ in THF solution at $25^{\circ} \mathrm{C}$, the obtained solution was timely monitored to high resolution mass spectroscopy after suitably dilution, an unexpected peak was checked at m/z 272.1228 in accord with DPT- $\mathbf{N}_{2} \mathrm{H}_{4}\left(\mathrm{C}_{15} \mathrm{H}_{18} \mathrm{~N}_{3} \mathrm{~S}\right.$, Exact Mass: $[\mathrm{M}+\mathrm{H}]^{+}$272.1221) (Fig. S7). Therefore, all these data supports the hydrazine-triggered addition-cyclisation-retro aldol recognition mechanism.

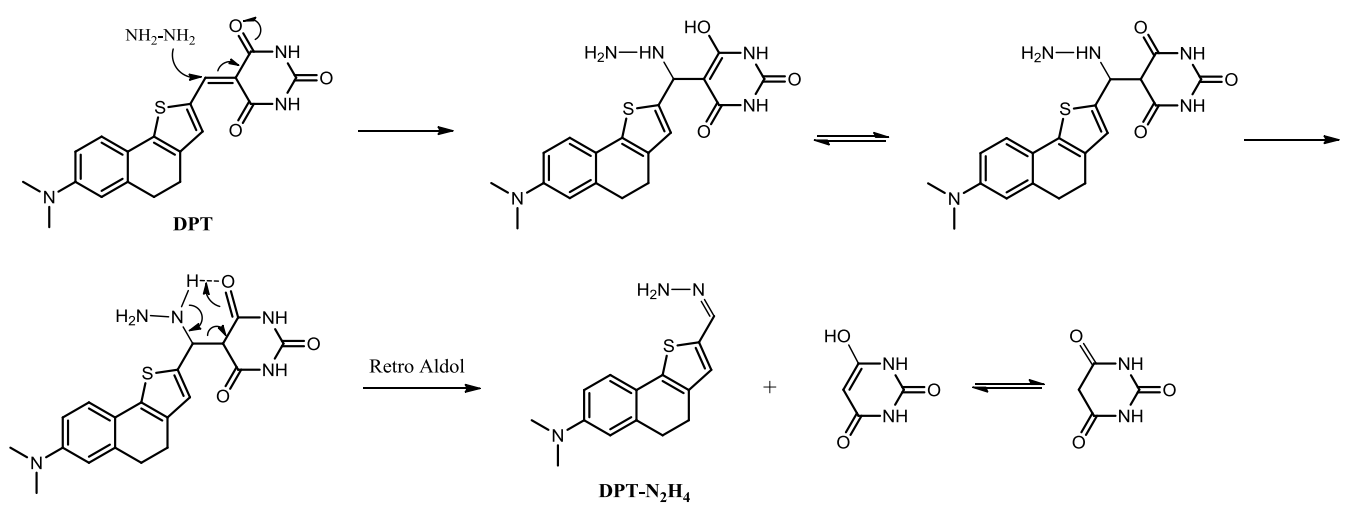

Scheme 2. Proposed mechanism for the reaction of probe DPT with $\mathrm{N}_{2} \mathrm{H}_{4} \cdot \mathrm{H}_{2} \mathrm{O}$.

To roundly comprehend the spectral changes of probe DPT responding to hydrazine, theoretical calculations were executed to use TD-DFT (time dependent density functional theory) with the PBE0/6-31+G(d, p) in a suite of the Gaussian 09 program. The solvent effects were thought about in DMSO by the polarizable continuum model (PCM) [43]. The optimized geometries and the HOMO and LUMO of probe DPT and DPT- $\mathbf{N}_{2} \mathbf{H}_{4}$ are presented in Fig. S8. Molecular orbital surfaces of the HOMO and LUMO for probe DPT and additive product DPT- $\mathbf{N}_{2} \mathbf{H}_{4}$ were shown in Fig. 7. For probe DPT, the electron density of the HOMO was spread across the whole probe scaffold. On the contrary, that of the LUMO was concentrated on the thiofuran part and barbituric acid moiety, respectively. As for DPT- $\mathbf{N}_{2} \mathbf{H}_{4}$, the electron in HOMO and LUMO orbital was chiefly spread over the naphthalene skeleton. Remarkably, ICT process didn't occur in the DPT-N $\mathbf{N}_{2} \mathbf{H}_{4}$, in that a $\mathrm{sp}^{2}$ hybridized carbon atom existed in thiofuran. The disruption of the ICT course generated in the raised HOMO-LUMO energy gap of DPT- $\mathbf{N}_{\mathbf{2}} \mathbf{H}_{\mathbf{4}}(3.598 \mathrm{eV})$ 
compared with that of the DPT $(2.671 \mathrm{eV})$. These above calculations result confirmed that $\mathrm{N}_{2} \mathrm{H}_{4} \cdot \mathrm{H}_{2} \mathrm{O}$ was reacted to the barbituric acid moiety and are identical with the spectra data.

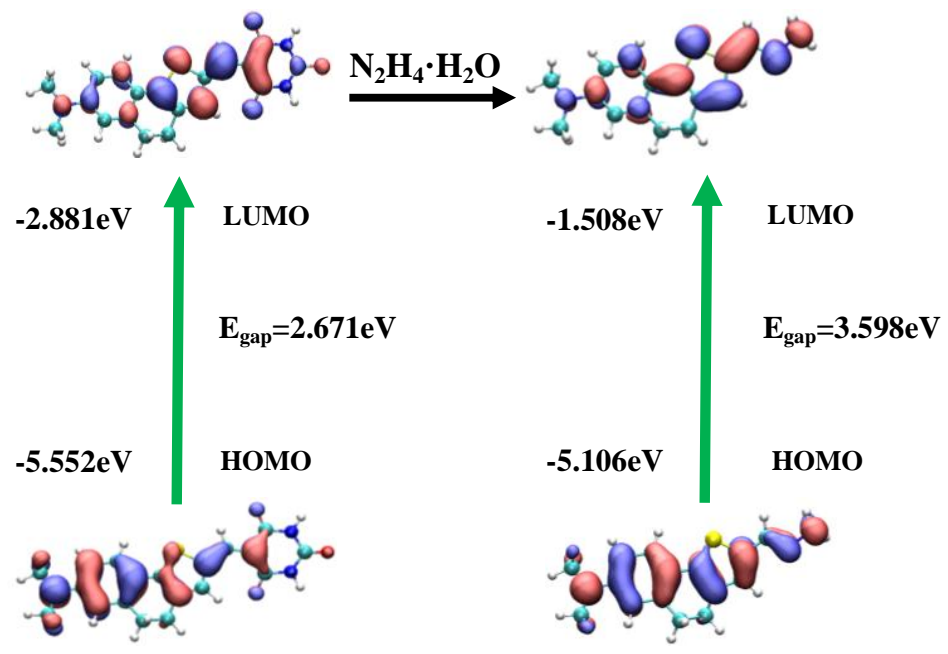

Fig. 7. HOMO-LUMO energy levels and frontier molecular orbital of probe DPT and the adduct DPT- $\mathbf{N}_{2} \mathbf{H}_{4}$.

3.6. Cytotoxicity and bioimaging in living cells

It is great concern to safety of probe DPT on living SH-SY5Y neuroblastoma cells. The cellular viability of probe DPT was estimated to be greater than $90 \%$ after 1 $\mathrm{h}$ at $10 \mu \mathrm{M}$ concentration, and the cellular viability was $75 \%$ at the concentration of $25 \mu \mathrm{M}$ by CCK-8 assay using standard cell viability protocols (Fig. S9). Briefly, probe DPT was the low cytotoxicity in SH-SY5Y neuroblastoma cells, these results suggest that probe DPT could be applied for detecting the $\mathrm{N}_{2} \mathrm{H}_{4} \cdot \mathrm{H}_{2} \mathrm{O}$ level in living cells.

Next, the ability of probe DPT to visualize hydrazine in live cell was also studied by using fluorescence microscopic imaging (Fig. 8). SH-SY5Y neuroblastoma cell was incubated with $10 \mu \mathrm{M}$ probe DPT and incubated with DPT $(10 \mu \mathrm{M})$ followed by hydrazine $(20 \mu \mathrm{M})$ in DMEM at $37^{\circ} \mathrm{C}$, respectively. The incubation time was $10 \mathrm{~min}$. Weak fluorescence was detected at blue channel in the cytoplasm. After addition of hydrazine $(20 \mu \mathrm{M})$, strong fluorescence signal was observed at the blue channel, suggesting the reaction of probe DPT with hydrazine. The high stability, low toxicity and excellent bioimaging make probe DPT a successful imaging tool for hydrazine. 


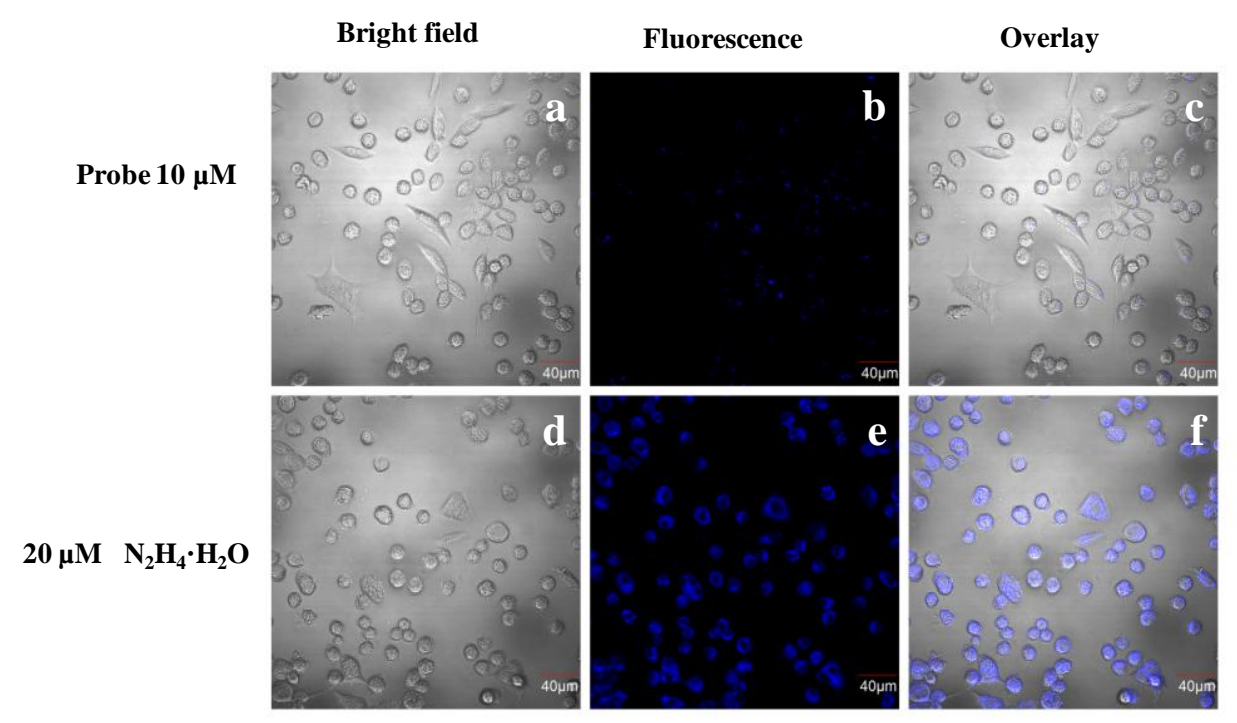

Fig. 8. Confocal fluorescence microscopic images of SH-SY5Y neuroblastoma cells. that cells incubated by probe DPT $(10 \mu \mathrm{M})$ for $10 \mathrm{~min}$ at $37^{\circ} \mathrm{C}$ and observed under bright field (a), blue channel (b), overlay (c), then further incubation with $\mathrm{N}_{2} \mathrm{H}_{4} \cdot \mathrm{H}_{2} \mathrm{O}(20 \mu \mathrm{M})$ for $15 \mathrm{~min}$ at $37{ }^{\circ} \mathrm{C}$ and observed under bright field, blue channel, overlay.

\section{Conclusion}

In conclusion, a novel on-off fluorescent probe was concise synthesized with barbituric acid as unique recognition group for detection of $\mathrm{N}_{2} \mathrm{H}_{4} \cdot \mathrm{H}_{2} \mathrm{O}$ via simply three steps. A novel recognition mechanism based on the hydrazine-triggered addition-cyclisation-retro aldol process was proposed and confirmed by HRMS. Probe DPT exhibits low limit of detection, large Stokes shift and broad $\mathrm{pH}$ tolerability range in practical applications. Additionally, probe DPT can be successfully implemented to indicate exogenous bioimaging of $\mathrm{N}_{2} \mathrm{H}_{4} \cdot \mathrm{H}_{2} \mathrm{O}$ in SH-SY5Y neuroblastoma cells with negligible cytotoxicity and excellent biocompatibility. Moreover, we desire that a novel probe DPT could be utilized to advance disclose some necessary information of hydrazine in extensive samples.

\section{Acknowledgements}

Thank for the Program for Changjiang Scholars and Innovative Research Team in University (No. IRT-15R55), Scientific Research Program Funded by Shaanxi Provincial Education Department (No. 18JK0774), the International Science \& Technology Cooperation Program of Shaanxi Province (No. 2019KWZ-001), Program of Innovation for Undergraduates of Northwest University (No. 2019253), 
Program of Graduate Quality Improvement of Northwest University (No. YZZ17169).

\section{Appendix A. Supplementary data}

Supplementary data associated with this article can be found, in the online version, at http://

\section{References}

[1] J. Sanabria-Chinchilla, K. Asazawa, T. Sakamoto, K. Yamada, H. Tanaka, P. Strasser, J. Am. Chem. Soc., 2011, 133, 5425-5431.

[2] A. Serov, M. Padilla, A. J. Roy, P. Atanassov, T. Sakamoto, K. Asazawa, H. Tanaka, Angew. Chem., Int. Ed., 2014, 53, 10336-10339.

[3] J. P. Schirmann, P. Bourdauducq, Ullmann's Encyclopedia of Industrial Chemistry, Wiley-VCH, Weinheim, 2002.

[4] C. A. Reilly, S. D. Aust, Chem. Res. Toxicol., 1997, 10, 328-334.

[5] G. Wang, C. Zhang, X. He, Z. Li, X. Zhang, L. Wang, B. Fang, Electrochim. Acta, 2010, 55, 7204-7210.

[6] U. S. E. P. A., Integrated Risk Information System (IRIS) on Hydrazine/Hydrazine Sulfate. National Center for Environmental Assessment, Office of Research and Development Washington, D. C., 1999.

[7] U. S. E. P. A., Hydrazine Hazard Summary-Created in April 1992; Revised in January 2000, Office of Research and Development Washington, D. C., 2008.

[8] S. D. Zelnick, D. R. Mattie, P. C. Stepaniak, Aviat. Space. Env. Med., 2003, 74, 1285-1291.

[9] M. J. Sun, L. Bai, D. Q. Liu, J. Pharm. Biomed. Anal., 2009, 49, 529-533.

[10] A. Umar, M. M. Rahman, S. H. Kim, Y. B. Hahn, Chem. Commun., 2008, 166-168.

[11] J. Liu, W. Zhou, T. You, F. Li, E. Wang, S. Dong, Anal. Chem., 1996, 68, 3350-3353.

[12] A. Benvidi, P. Kakoolaki, H. R. Zare, R. Vafazadeh, Electrochim. Acta, 2011, 56, 2045-2050.

[13] J. Cheng, E. Yang, P. Ding, J. Tang, D. Zhang, Y. Zhao, Y. Ye, Sens. Actuators, B, 2015, 221, $688-93$.

[14] A. Safavi, M. A. Karimi, Talanta, 2002, 58, 785-92.

[15] Z. He, B. Fuhrmann, U. Spohn, Anal. Chim. Acta, 2000, 409, 83-91.

[16] (a) W. Y. Feng, G.Q. Feng, Dyes Pigm., 2019, 164, 174-181; (b) J. X. Hong, W. Y. Feng, G. Q. Feng, Sens. Actuators, B, 2018, 262, 837-844; (c) W. Y. Feng, S. Y. Gong, E. B. Zhou, X. Y. Yin, G. Q. Feng, Anal. Chim.Acta, 2018, 1029, 97-103.

[17] S. Nandi, A. Sahana, S. Mandal, A. Sengupta, A. Chatterjee, D. A. Safin, M. G. Babashkina, N. A. Tumanov, Y. Filinchuk, D. Das, Anal. Chim. Acta, 2015, 893, 84-90.

[18] Y. D. Lin, T. J. Chow, RSC Adv., 2013, 3, 17924-17929.

[19] S. Goswami, S. Paul, A. Manna, RSC Adv., 2013, 3, 18872-18877. 
[20] M. G. Choi, J. Hwang, J. O. Moon, J. Sung, S. K. Chang, Org. Lett., 2011, 13, 5260-5263.

[21] H. Tse, Q. H. Li, S. M. Chan, Q. H. You, W. M. Lee, W. H. Chan, RSC Adv., 2016, 6, 14678-14681.

[22] X. D. Jiang, J. Guan, H. Bian, Y. Xiao, Tetrahedron Lett., 2017, 58, 2351-2354.

[23] T. Tang, Y. Chen, B. S. Fu, Z. Y. He, H. Xiao, F. Wu, J. Q. Wang, S. R. Wang, X. Zhou, Chin. Chem. Lett., 2016, 27, 540-544.

[24] S. Goswami, S. Das, K. Aich, B. Pakhira, S. Panja, S. K. Mukherjee, S. Sarkar, Org. Lett., 2013, 15, 5412-5415.

[25] J. Zhou, R. Y. Shi, J. X. Liu, R. Wang, Y. F. Xu, X. H. Qian, Org. Biomol. Chem., 2015, 13, 5344-5348.

[26] C. Hu, W. Sun, J. F. Cao, P. Gao, J. Y. Wang, J. L. Fan, F. L. Song, S. G. Sun, X. J. Peng, Org. Lett., 2013, 15, 4022-4025.

[27] Z. L. Lu, W. L. Fan, X. M. Shi, Y. N. Lu, C. H. Fan, Anal. Chem., 2017, 89, 9918-9925.

[28] J. Fan, W. Sun, M. Hu, J. Cao, G. Cheng, H. Dong, K. Song, Y. Liu, S. Sun, X. Peng, Chem. Commun., 2012, 48, 8117-8119.

[29] Y. Tan, J. Yu, J. Gao, Y. Cui, Y. Yang, G. Qian, Dyes Pigm., 2013, 99, 966-971.

[30] Y. Sun, D. Zhao, S. Fan, L. Duan, Sens. Actuators, B, 2015, 208, 512-517.

[31] (a) K. Li, H. R. Xu, K. K. Yu, J. T. Hou, X. Q. Yu, Anal. Methods, 2013, 5, 2653-2656; (b) Q. S. Zhai, W. Y. Feng, G. Q. Feng, Anal.Methods, 2016, 8, 5832-5837.

[32] B. Liu, Q. Liu, M. Shah, J. Wang, G. Zhang, Y. Pang, Sens. Actuators. B, 2014, 202, 194-200.

[33] L. Xiao, J. Tu, S. Sun, Z. Pei, Y. Pei, Y. Pang, Y. Xu, RSC Adv., 2014, 4, 41807-41811.

[34] X. Chen, X. Yu, Z. Li, A. Tong, Anal. Chim. Acta, 2008, 625, 41-46.

[35] L. Cui, Z. Peng, C. Ji, J. Huang, D. Huang, J. Ma, S. Zhang, X. Qian, Y. Xu, Chem. Commun., 2014, 50, 1485-1487.

[36] L. Cui, C. Ji, Z. Peng, L. Zhong, C. Zhou, L. Yan, Anal. Chem., 2014, 86, 4611-4617.

[37] S. Goswami, S. Das, K. Aich, B. Pakhira, S. Panja, S. K. Mukherjee, S. Sarkar, Org. Lett., 2013, 15, 5412-5415.

[38] Y. Qian, J. Lin, L. Han, L. Lin, H. Zhu, Biosens. Bioelectron., 2014, 58, 282-286.

[39] X. Jin, C. Liu, X. Wang, H. Huang, X. Zhang, H. Zhu, Sens. Actuators. B, 2015, 216, 141-149.

[40] L. Q. Cui, Z. L. Dong, K. Liu, C. Zhang, Org. Lett., 2011, 13, 6488-6491.

[41] C. Herbivo, A. Comel, G. Kirsch, M. Manuela, M. Raposo, Tetrahedron, 2009, 65, 2079-2086.

[42] T. Sun, Q. F. Niu, Y. Li, T. D. Li, T. T. Hu, E. H. Wang, H. X. Liu, Sens. Actuators. B, 2018, 258, 64-71

[43] J. Tomasi, B. Mennucci, E. Cancès, J. Mol. Struct. (Theochem), 1999, 464, 211-226. 